\title{
Re-thinking informal entrepreneurship: Commercial or social entrepreneurs?
}

\section{Colin C. Williams* and Sara Nadin}

\author{
Management School, \\ University of Sheffield, \\ 9 Mappin Street, \\ Sheffield S1 4DT, UK \\ E-mail: C.C.Williams@sheffield.ac.uk \\ E-mail: S.J.Nadin@sheffield.ac.uk \\ ${ }^{*}$ Corresponding author
}

\begin{abstract}
This paper evaluates critically the assumption that entrepreneurs who start-up their business ventures operating wholly or partially off-the-books are engaged in commercial entrepreneurship. Reporting evidence from a 2005-2006 survey involving face-to-face interviews with 298 informal entrepreneurs in Ukraine, the finding is that they are not all commercially-driven. Instead, these informal entrepreneurs range from purely rational economic actors who pursue for-profit logics through to purely social entrepreneurs who pursue solely social logics, with the majority somewhere in the middle of this spectrum combining both for-profit and social rationales. The result is a call for a more nuanced understanding of the heterogeneous logics of informal entrepreneurs that recognises the existence of social entrepreneurs in the realm of informal entrepreneurship.
\end{abstract}

Keywords: informal sector; shadow economy; hidden economy; underground economy; commercial entrepreneurship; social entrepreneurship; enterprise culture; post-socialist economies; Ukraine.

Reference to this paper should be made as follows: Williams, C.C. and Nadin, S. (2012) 'Re-thinking informal entrepreneurship: Commercial or social entrepreneurs?', Int. J. Social Entrepreneurship and Innovation, Vol. 1, No. 3, pp.295-309. Biographical notes: Colin C. Williams is in the Centre for Regional
Economic and Enterprise Development (CREED) in the Management School
at the University of Sheffield. His books include The Informal Economy
in Developed Nations (2010, Palgrave-Macmillan), The Hidden Enterprise
Culture (2006, Edward Elgar) and A Commodified World? mapping the limits
of capitalism (2005, Zed). He has published some 20 books and 250 journal
papers on these issues over the past 25 years.

Sara Nadin is a Lecturer in Organisational Behaviour in the Management School at the University of Sheffield. Her research interests are in the informal economy, small businesses, entrepreneurship and the psychological contract between employers and employees. 


\section{Introduction}

Over the past decade or so, a small stream of entrepreneurship has drawn attention to how many entrepreneurs start-up their ventures trading partially or wholly on an off-the-books basis in the informal economy (Aidis et al., 2006; Evans et al., 2006; Gurtoo, 2009; Gurtoo and Williams, 2009; Llanes and Barbour, 2007, Smallbone and Welter, 2004; Williams, 2006, 2009a, 2009b). Until now, the assumption has been that these informal entrepreneurs are exclusively commercial entrepreneurs; they are assumed to be rational economic actors who have weighed up the benefits of working legitimately against the risks and penalties of being caught and decided to operate informally. The aim of this paper is to evaluate critically this a priori assumption about the nature of informal entrepreneurship. To do so, evidence from a 2005-2006 survey of 298 informal entrepreneurs in Ukraine is reported.

To achieve this, the first section will review the current literature on informal entrepreneurship along with the literature on the commercial Vs. social entrepreneurship dualism that represents entrepreneurs and entrepreneurship as either commercial or social. Secondly, and to evaluate critically whether all informal entrepreneurs are commercial entrepreneurs, a 2005-2006 survey conducted in Ukraine with 298 informal entrepreneurs will be reported. This will reveal that informal entrepreneurs range from purely for-profit driven to purely social entrepreneurs, with the majority somewhere in-between combining both for-profit and social rationales. The outcome will be a call to recognise the diverse rationales of informal entrepreneurs.

Before commencing, nevertheless, a working definition of informal entrepreneurship is required as well as commercial and social entrepreneurship. In this paper, informal work is defined as monetary transactions not declared to the state for tax and/or benefit purposes when they should be declared but which are legal in all other respects (e.g., European Commission, 2007; Evans et al., 2006; Renooy et al., 2004; Williams, 2006). An entrepreneur, meanwhile, is somebody actively involved in starting a business or is the owner/manager of a business less than 36 months old (Harding et al., 2005; Reynolds et al., 2002). Informal entrepreneurship, therefore, refers to those starting a business or are the owner/manager of a business less than 36 months old who engage in monetary transactions not declared to the state for tax and/or benefit purposes when they should be declared but which are legal in all other respects. Furthermore, commercial entrepreneurship refers to those actively involved in starting a business or are the owner/manager of a business that is less than 36 months old which is grounded in a for-profit objective. Social entrepreneurs, in contrast, are driven not by the need to maximise profit for shareholders or owners, but by the creation of social value (Austin et al., 2006; Defourny and Nyssens, 2008; Zadek and Thake, 1997). Social entrepreneurship is thus defined as somebody actively involved in starting a business or is the owner/manager of a business that is less than 36 months old which has a social and/or environmental objective in either the non-profit, for-profit or government sectors (e.g., Dees, 1998; Dees and Anderson, 2003; Emerson and Twersky, 1996). 


\section{Informal entrepreneurs and the commercial/social entrepreneurship dichotomy}

\subsection{Informal entrepreneurship}

Until now, the literature on entrepreneurship has been dominated by a wholesome, positive and virtuous representation of the entrepreneur as a super-hero (Burns, 2001; Cannon, 1991). The result is that forms of entrepreneurship tarnishing this ideal-type are either represented as existing outside the boundaries of entrepreneurship, ignored, depicted as temporary or transient, or said to have little to do with what is perceived as mainstream entrepreneurship, namely the study of legitimate entrepreneurs.

Recently, however, a small stream of entrepreneurship literature has built upon the earlier tradition that drew attention to the negative attributes of entrepreneurship and how entrepreneurs do not always play by the rulebook (Collins et al., 1964; Bhide and Stevenson, 1990; Kets de Vries, 1977). This documents how entrepreneurs engage in illegitimate acts (Armstrong, 2005; Bouchard and Dion, 2009; Deutschmann, 2001; Fournier, 1998; Friman, 2001; Frith and McElwee, 2008, 2009; Jones and Spicer, 2005, 2006; Rehn and Taalas, 2004; Sköld and Rehn, 2007; Smith, 2007; Smith and Christou, 2009; Storr and Butkevich, 2007) and how those partaking in illegitimate activities often display entrepreneurial traits, such as drug-dealers (Bouchard and Dion, 2009; Frith and McElwee, 2008, 2009; Friman, 2001) and prostitutes and pimps (Smith and Christou, 2009).

Beyond this literature on entrepreneurs trading illegitimate goods and services, a further stream has begun to show how entrepreneurs trading legitimate goods and services do not declare some or all their transactions to the authorities for tax and social security purposes when they should be declared (e.g., Antonopolous and Mitra, 2009; Ram et al., 2007; Small Business Council, 2004; Valenzuela, 2001; Williams, 2006, 2007a, 2007b, 2007c, 2008, 2009a, 2009b; Williams and Round, 2007, 2008; Williams et al., 2009a, 2009b). It is not only the entrepreneurship literature however, that has started to uncover the existence of informal entrepreneurship.

The literature on the informal economy has also started to analyse the relationship between entrepreneurship and informality. Identifying that much informal work is conducted on an own-account basis, rather than as waged labour, the informal economy has been increasingly re-represented as a 'hidden enterprise culture' and informal workers as entrepreneurs (De Soto, 2001; ILO, 2002a, 2002b; Rehn and Taalas, 2004; Round et al., 2008; Small Business Council, 2004; Williams, 2006, 2008; Williams and Round, 2007, 2008). As the ILO (2002a, p.54) for example state, the informal economy represents 'an incubator for business potential and transitional base for accessibility and graduation to the formal economy' and the informal self-employed display 'real business acumen, creativity, dynamism and innovation'.

Until now, however, few have evaluated the commonality of informality in new and established businesses. One of the few studies to do so reveals that in Russia, Ukraine and England, 100, 90 and 77\% respectively of the entrepreneurs surveyed operate in the informal economy (Williams, 2008). This reveals how informality is normality amongst informal entrepreneurs. 


\subsection{Informal entrepreneurship: Commercial or social entrepreneurs?}

In this burgeoning literature, nevertheless, few seldom question the logics underpinning informal entrepreneurship. The widespread assumption has been that informal entrepreneurship is a form of commercial entrepreneurship. The depiction is that informal entrepreneurs are rational economic actors who weigh up the benefits of working informally against the costs of being caught in terms of the penalties and risks of detection, and decide to operate informally. This is advocated by the two dominant schools of thought on informal entrepreneurship.

On the one hand, there is a neo-liberal perspective that portrays informal entrepreneurship as voluntarily engaged in by those viewing taxes as too high and over-regulation by the state as stifling entrepreneurial spirit. For these neo-liberals, therefore, informal entrepreneurs are rational economic actors casting off the bureaucratic shackles of an over-regulated state (e.g., De Soto, 1989) and choosing to work in the informal economy to avoid the costs, time and effort of formal registration (Biles, 2009; De Soto, 1989, 2001; Maloney, 2004; Packard, 2007; Perry and Maloney, 2007; Small Business Council, 2004).

On the other hand, there is a structuralist perspective. In the unfolding de-regulated open world economy, the growth of sub-contracting is asserted to have resulted in the expansion of forms of dependent or false self-employment as well as informal waged labour. Again, this is seen as a rational economic decision of firms to employ unregulated, low paid, precarious and insecure workers under 'sweatshop-like' conditions (Amin et al., 2002; Castells and Portes, 1989; Davis, 2006; Gallin, 2001; Portes, 1994). Consequently, the notion that informal entrepreneurship is anything other than profit-driven capitalist endeavour is seldom entertained. In both perspectives, informal entrepreneurship is a by-word for contemporary de-regulated capitalist culture.

Unlike the mainstream literature on entrepreneurship and enterprise culture, where it is widely accepted that entrepreneurship is not always entirely profit-driven and how social rationales are often involved (Defourny and Nyssens, 2008; Galera and Borzega, 2009; Hynes, 2009; Lyon and Sepulveda, 2009; Nicholls and Cho, 2006; Thompson, 2008), this has not been considered with regard to informal entrepreneurship.

The intention in this paper, therefore, is to evaluate whether informal entrepreneurs are commercial entrepreneurs and economically driven as rational economic actors to operate informally. To evaluate this, and learning from the mainstream entrepreneurship literature, the dichotomous portrayal of commercial and social entrepreneurship as separate and wholly discrete dualistic opposites will need to be transcended. Indeed, the need to transcend this dualistic portrayal has begun to be widely recognised when studying legitimate entrepreneurs (Austin et al., 2006; Mair and Martí, 2005; Moore et al., 2010). As Austin et al. (2006, p.3) assert,

\footnotetext{
"The distinction between social and commercial entrepreneurship is not dichotomous, but rather more accurately conceptualised as a continuum ranging from purely social to purely economic."
}

The growing recognition, therefore, is that social and commercial objectives are commonly combined and that entrepreneurs give different weights to these logics. As Moore et al. (2010, p.52) put it, 


\begin{abstract}
"Becoming a social entrepreneur usually does not mean that one is no longer concerned with making money - financial gain is just one of an expanded set of goals sometimes referred to as the 'triple bottom line' because they focus on people, profit and the planet."
\end{abstract}

In sum, until now, the literature on informal entrepreneurship has largely concentrated on analysing whether informal entrepreneurs' motives are necessity - or opportunity-driven (Cross, 1997, 2000; Gerxhani, 2004; Snyder, 2004; Williams, 2007a, 2007c, 2008). Whether or not they are also purely for-profit driven or whether social logics are also involved has not been considered.

\title{
3 Evaluating informal entrepreneurship in Ukraine: commercial or social entrepreneurs?
}

To begin to bridge this gap in the literature on informal entrepreneurship, empirical evidence is here reported collected in Ukraine. Similar to the other successor states of the former Soviet Union, the transition to a market society has not been a smooth untroubled process in Ukraine. Between 1990 and 1999, official employment declined by about one-third (Chernyshev, 2006), 73\% of Ukrainians receive insufficient from their main income to buy what they need (Rose, 2005), with $80 \%$ receiving an income lower than the minimum subsistence level (Moisala, 2004). In most global league tables, moreover, Ukraine is near the bottom in terms of its corruption levels, transparency in public life, tax morality and barriers to formalisation (Anderson and Gray, 2006; Hanson, 2006; Knott and Miller, 2006; Transparency International, 2005). Given this, it would be surprising if informal entrepreneurship was not rife in this country.

\subsection{Methodology}

Those new to the study of informal entrepreneurship might assume that researching this issue will be problematic due to its hidden nature. However, previous studies have shown that even if this endeavour is hidden from the state for tax and social security purposes, this does not mean that entrepreneurs do not openly discuss such practices with academic researchers (Leonard, 1994; MacDonald, 1994; Pahl, 1984; Williams, 2004, 2006).

In late 2005 and early 2006, therefore, an empirical study of informal entrepreneurship in Ukraine was conducted. Given that previous studies elsewhere reveal significant disparities in the level and nature of informal entrepreneurship between affluent and deprived as well as urban and rural populations (Williams, 2007a, 2007b, 2007c), maximum variation sampling was used to select four contrasting localities. Firstly, and in the capital of Kiev, an affluent district was chosen, namely Pechersk, heavily populated by government officials and the new business class, along with a deprived district, namely Vynogardar, comprised of dilapidated Soviet-era housing with high unemployment and widespread poverty. Continuing the process of maximum variation sampling, the deprived rural area of Vasilikiv was then chosen, which heavily relied on a nearby refrigerator manufacturing plant for its employment until it closed nearly 10 years ago and since then has suffered high unemployment, and finally, a town on the Ukrainian/Slovakia border was selected, Užhgorod, which is the fairly affluent capital of the Carpathian region. 
In each locality, a household rather than a business premise survey was conducted. This is because firstly, many businesses are home-based (Mason et al., 2009) and would have been missed by a business premise survey, and secondly a household survey enables this sensitive issue to be discussed in the supportive context of the "wide range of livelihood practices being used by households to get-by in these difficult times". This positioned informal entrepreneurship as one of a range of practices being used by households during this difficult transition period.

A spatially stratified sampling methodology was used to select the households for interview in each locality (Kitchen and Tate, 2001). If there were some 1000 households in the district and 100 interviews were sought, that is, the researcher called at every 10th household. If there was no response and/or an interview was refused, then the 11th household was visited, then the 9th, 12th, 8th and so on. This provided a spatially stratified sample of each locality. In total, 600 face-to-face interviews were conducted in the four localities; 150 in each locality. This provided a spatially stratified sample of each district. It meant that the interviews were representative and stopped the sample being skewed towards certain tenures, types of dwelling and different parts of the district being interviewed. For each household, furthermore, the 'closest birthday' rule was used to select respondents for interview amongst those available in the household at the time.

A relatively structured face-to-face interview schedule was used to gather information on household livelihood practices. Here, solely the sections of the questionnaire relevant to whether they engaged in commercial and/or social entrepreneurship are outlined. Firstly, socio-demographic background data was collected on the household in terms of the age, gender, employment status and work history of household members as well as gross household income, including whether any household member had started-up a business venture in the past 36 months. Secondly, the nature of their business venture was investigated including the number employed, the length of time it had existed and economic sector. And thirdly, the logics of these entrepreneurs were investigated both at the start-up of their business and at the time of the interview. Respondents were first asked whether their business venture was primarily a for-profit enterprise or established for other social purposes. The definitions explicitly stated to respondents that commercial entrepreneurship is where somebody seeks to maximise profit while social entrepreneurship is where somebody starts some kind of social, voluntary or community enterprise for primarily social/environmental objectives. Following this initial question, two further probes were then used to elicit additional information on their rationales. These firstly asked "are there any other reasons besides this main one" and secondly, inflected the first response such as "purely commercially-motivated?". Finally, they were asked whether their objectives had changed over time. Below, the findings are reported.

\subsection{Findings}

The 600 face-to-face interviews revealed a high-level of entrepreneurship in contemporary Ukraine. Some 331 individuals asserted that they had started-up an enterprise in the past three years. Of these, just $33(10 \%)$ stated that their business ventures were wholly legitimate operations that were registered with the state, in possession of the required licenses and conducted all transactions on-the-books. The remaining 298 entrepreneurs (90\%) operated wholly or partially off-the-books. Some $39 \%$ had a license to trade and/or the person was registered as self-employed but traded 
partially off-the-books, while $51 \%$ operated wholly unregistered with no license to trade and transactions were wholly of-the-books. Over half of all enterprises, therefore, are not even on the radar screen of the state.

To evaluate whether these were commercial or social enterprises, those 298 who had started-up enterprises during the past 36 months were asked, "why did you decide to start this enterprise?". Of the 298 early-stage entrepreneurs surveyed, 75\% reported operating commercial (profit-driven) enterprises and 25\% social enterprises. Indeed, examining the spatial variations in the nature of entrepreneurship, Table 1 displays that the ratio of social-to-commercial entrepreneurs, therefore, varies across the localities surveyed. In the deprived district of Kiev, a greater proportion of entrepreneurs operate social enterprises whilst in the affluent Kiev district they are more likely to operate commercial enterprises.

Table 1 Main logic for participating in informal entrepreneurship in Ukraine: by locality-type

\begin{tabular}{|c|c|c|c|c|c|}
\hline Rationale & All areas & $\begin{array}{c}\text { Deprived Kiev } \\
\text { district }\end{array}$ & $\begin{array}{c}\text { Affluent Kiev } \\
\text { district }\end{array}$ & $\begin{array}{c}\text { Border } \\
\text { town }\end{array}$ & $\begin{array}{l}\text { Rural } \\
\text { area }\end{array}$ \\
\hline & $\%(n=298)$ & $\%(n=71)$ & $\%(n=83)$ & $\%(n=78)$ & $\%(n=66)$ \\
\hline Commercial & 75 & 62 & 84 & 76 & 77 \\
\hline Social & 25 & 36 & 16 & 24 & 23 \\
\hline Total & 100 & 100 & 100 & 100 & 100 \\
\hline
\end{tabular}

In major part, this is because in the affluent Kiev district, the business start-up has emerged out of their formal occupation and they engage in relatively well-paid off-the-books self-employment related to their formal job ( $85 \%$ of business ventures), conducting what might be interpreted as off-the-books 'consultancy' or 'on-the-side' work. Examples are university teachers providing preparation for the university entrance examinations, school teachers providing after-school additional lessons for pupils, software engineers providing informal services for the clients of their formal employer, and self-employed plumbers, electricians and builders doing a portion of their trade off-the-books. In the deprived Kiev district, meanwhile, fewer use the skills and networks arising from their formal occupation. Instead, it arises out of need identified to exist in the community and/or some interest. Examples include a man who sells individual cigarettes at a bus terminus and a street flower seller who operates just outside a market.

In the border town and rural area, meanwhile, informal entrepreneurship is more polarised. On the one hand, amongst the higher-income quartiles, there is relatively well-paid informal entrepreneurship often arising out of their legitimate employment and comprising 'on-the-side' or 'off-the-books' consultancy. This includes the off-the-books enterprises of not only formal employees but also the crafts-based self-employed (e.g., electricians, plumbers, plasterers, general builders). An example is 'Rus', employed in a state-owned firm as a plumber, who engages in home repairs as 'podrabotka' (extra unofficial work). Although he has no employees, he works as part of a 'brigada' in collaboration with others who all also have formal jobs and engage in home repair and improvement work informally. On the other hand, and amongst the lower-income quartiles, the work tends not to arise out of their formal jobs, and to be lower-skilled and lower-paid. 
It might be assumed from the above that these are all commercial entrepreneurs pursuing a profit-driven motive for their own monetary gain. However, as Table 1 reveals, this is not the case. Some $75 \%$ had primarily commercial objectives for setting up their business. Common explanations were "state benefits do not even pay food costs", "I had no other option if I wanted to buy things like clothes for my children and food", "I had to do this in order to make enough money to buy the necessities of life", "if I hadn't, I would have starved", and "I had no other choice if I was going to earn enough to survive".

The remaining $25 \%$ of nascent entrepreneurs expressed primarily social rationales. Some recounted personal social rationales such as a quest for autonomy in their work, to achieve a work-life balance or to forge a new social identity. As a woman in the mixed district asserted, "My business [catering for business functions] allows me to express who I am". Or as a plumber put it, "if I did not do such jobs off-the-books for people, they would freeze in the cold winters". Meanwhile, a woman child-carer for various families asserted, "I do it for one family so that she can study, for another to allow her to work and for another because she cannot afford the state nursery". Or as 'Katrina', in her mid-40s, explains.

\begin{abstract}
"About three years ago, a good friend of mine was working at the time in a school and in conversation with him I realised that there was no canteen and no cheap cafes nearby. So I volunteered to prepare meals for the 15 staff at a really cheap price just to help them out. I covered my costs but it was a kindness thing really."
\end{abstract}

Later, she expanded her business by seeking out other groups with similar unmet needs.

These, however, are all examples of private enterprises with primarily social goals. Besides these ventures, there were also entrepreneurs running voluntary or community groups for primarily social rationales. An example of a social entrepreneur is a man who asserted "I run a keep-fit class for mothers to give them a chance to get together. It gives them an excuse to get out of the house for a few hours and meet others like them".

So far, however, we have examined solely their main rationale and based on this, it might well be assumed that it is valid to dichotomously depict entrepreneurs as participating in either commercial or social entrepreneurship. However, when the two further probes that followed this initial question are analysed, this dualistic division of entrepreneurs into either the commercial or social side is shown to be a simplification.

Table 2 reports the fuller logics of respondents when taking into account the two follow-up questions. These firstly repeated the answer given by the respondent with an inflexion (e.g., "to make money?") and secondly, asked in an open ended manner "any other reasons?". When the responses to these probes are included, the result is a rather different representation of entrepreneurs' logics. Just $45 \%$ of entrepreneurs rely purely on either a commercial or a social logic. The majority $(55 \%)$ combine both commercial and social logics, clearly signalling that the commercial/social entrepreneurship dualism that separates commercial and social logics is a misnomer. Most informal entrepreneurs possess both social and commercial logics, and tend to be clustered towards the commercial-oriented end of the continuum. 
Table 2 Fuller rationales for informal entrepreneurship: by locality-type

\begin{tabular}{lcccc}
\hline Respondent & Solely commercial & $\begin{array}{c}\text { Mainly commercial } \\
\text { but also social }\end{array}$ & $\begin{array}{c}\text { Mainly social but also } \\
\text { commercial }\end{array}$ & Solely social \\
\hline $\begin{array}{l}\text { All } \\
\text { Locality-type: }\end{array}$ & 35 & 40 & 15 & 10 \\
$\begin{array}{l}\text { Deprived Kiev } \\
\text { district }\end{array}$ & 26 & 36 & 20 & 16 \\
$\begin{array}{l}\text { Affluent Kiev } \\
\text { district }\end{array}$ & 46 & 38 & 10 & 6 \\
$\begin{array}{l}\text { Border town } \\
\text { Rural area }\end{array}$ & 40 & 36 & 15 & 9 \\
\hline
\end{tabular}

These fuller logics, nevertheless, also vary spatially. In the affluent Kiev district, informal entrepreneurs are more likely to be clustered towards the commercial end of the spectrum, whilst informal entrepreneurs in the deprived Kiev district are more socially-oriented in their logics, as do the border town and rural area. In the affluent Kiev district, border town and rural area, however, the social objectives tend to be often embedded in, and subsidiary to, commercial objectives. For example, an entrepreneur may do work at 'mate's rates' for customers who would not otherwise be able to afford to get the work completed (e.g., repairing the central heating). These customers are often previously known by the entrepreneur but not necessarily so. They are often older people or people on low incomes who would otherwise not be able to get the work done. In the deprived Kiev district, in contrast, social logics tend to be less often embedded within, and/or subservient to, commercial rationales, and more prominent in entrepreneurs' logics. In this district, that is, one is more likely to find more ventures driven by social logics, such as community associations and private business ventures with primarily social goals.

Entrepreneurs' logics also often alter over time. As Table 3 shows, some 51\% asserted that their rationales had altered since starting up the business and of these, $30 \%$ stated that it was away from commercial to social rationales and $21 \%$ from social to commercial rationales. As a result, it would be erroneous to write off informal entrepreneurs operating on a social basis as not being potential future catalysts of economic development. This study reveals that many such entrepreneurs become more commercially-driven over time.

Table 3 Shifts over time in reasons for engaging in informal entrepreneurship

\begin{tabular}{ll}
\hline & $\%$ \\
\hline Rationales unchanged & 49 \\
From more commercial to more social rationales & 30 \\
From more social to more commercial explanations & 21 \\
\hline
\end{tabular}

\section{Discussion and conclusions}

Drawing upon a survey of 298 informal entrepreneurs in Ukraine, this paper has evaluated whether all informal entrepreneurs operate within a commercial logic. 
Analysing their rationales, the finding is that many informal entrepreneurs do not pursue either purely profit-oriented or solely social goals. Rather, well over half (55\%) voice both commercial and social logics when explaining their entrepreneurial endeavour, displaying that there are not two separate and distinct types of entrepreneurship but rather a continuum from purely commercial to purely social entrepreneurship. The logics of informal entrepreneurship, nevertheless, vary spatially. Those in the deprived Kiev district tend to be more socially-orientated and clustered towards this end of the spectrum of types of entrepreneurship, whilst those in the relatively affluent Kiev district area are comparatively more profit-driven and clustered more towards this end of the spectrum, whilst the border town and rural area are somewhere in between. Neither, furthermore, do informal entrepreneurs' logics remain static. The majority (51\%) stated that their rationales had changed since starting up the business, with $30 \%$ stating that it was away from commercial to social rationales and $21 \%$ from social to commercial rationales.

These findings have important implications for both theorisations of informal entrepreneurship and for policy. On the one hand, informal entrepreneurship have been often assumed to be entirely profit-driven, constructed as rational economic actors who weigh up benefits of operating informally against the costs of doing so in terms of the penalties and risks of detection, and then make a decision to operate informally to maximum their financial gain. However, this is little more than an a priori assumption. It is not an evidence-based finding. This study is one of the first to evaluate critically this assumption. It tentatively reveals that many informal entrepreneurs operate as social actors, rather than rational economic actors, and engage in informal entrepreneurship with social logics as either their primary or subsidiary goals; some $65 \%$ of all entrepreneurs surveyed. The outcome is a tentative call to transcend the assumption that informal entrepreneurs are purely commercially-driven. This has been done by calling for informal entrepreneurs to be portrayed as existing on a continuum from purely commercial to purely social entrepreneurship, with different combinations of logics predominating in varying populations. This finding, however, is based on a relatively limited data set. Future investigations will need to evaluate not only where on the spectrum informal entrepreneurship is clustered in different populations but also the direction of change.

On the other hand, these findings have potentially important implications for public policy towards informal entrepreneurship. This study reinforces the current wide-ranging recognition that much work in the informal economy needs to be recognised as a hidden enterprise culture which needs to be harnessed (Williams, 2006). Unless this is achieved, economic policy will eradicate with one hand precisely the entrepreneurship and enterprise culture that with another hand it is seeking to nurture. However, it also raises for the first time the recognition that informal entrepreneurship is also often socially-driven. This also reinforces the need for informal entrepreneurship to be harnessed rather than eradicated. Unless this is done, then again government policy runs the risk of eradicating with one hand precisely the social entrepreneurship and citisenship that it again wishes to nurture.

To conclude, this paper has shown that informal entrepreneurship is not always commercially-driven. However, rather than depict some informal entrepreneurs as socially-driven and others as commercially-driven, it has instead revealed how most combine commercial and social logics and how their logics vary temporally and spatially. If the outcome is that further research is now encouraged to pursue a more nuanced 
mapping of informal entrepreneurs' logics and how they vary across different populations, so as to re-theorise not only the logics of informal entrepreneurs and the commercial vs. social entrepreneurship divide, but also how public policy needs to respond, then it will have fulfilled its objective.

\section{References}

Aidis, R., Welter, F., Smallbone, D. and Isakova, N. (2006) 'Female entrepreneurship in transition economies: the case of Lithuania and Ukraine', Feminist Economics, Vol. 13, No. 2, pp.157-183.

Amin, A., Cameron, A. and Hudson, R. (2002) 'The UK social economy: panacea or problem?', in Bartle, I. and Castiglione, D. (Eds.): Social Capital in the Economy, Russell Papers Civic Series 2002-2004, University of Essex, Colchester.

Anderson, J. and Gray, C. (2006) Anticorruption in Transition 3 Who Is Succeeding and Why? World Bank, http://siteresources.worldbank.org/INTECA/Resources/ACT3.pdf

Antonopolous, G.A. and Mitra, J. (2009) 'The hidden enterprise of bootlegging cigarettes out of Greece: two schemes of illegal entrepreneurship', Journal of Small Business and Entrepreneurship, Vol. 22, No. 1, pp.1-8.

Armstrong, P. (2005) Critique of Entrepreneurship: People And Policy, Palgrave Macmillan, Basingstoke.

Austin, J., Stevenson, H. and Wei-Skillern, J. (2006) 'Social and commercial entrepreneurship: same, different or both?', Entrepreneurship Theory and Practice, Vol. 31, No. 1, pp.1-22.

Bhide, A. and Stevenson, H.H. (1990) 'Why be honest if honesty doesn't pay?', Harvard Business Review, Vol. 68, No. 5, pp.121-129.

Biles, J. (2009) 'Informal work in Latin America: competing perspectives and recent debates', Geography Compass, Vol. 3, No. 1, pp.214-236.

Bouchard, M. and Dion, C.B. (2009) 'Growers and facilitators: probing the role of entrepreneurs in the development of the cannabis cultivation industry', Journal of Small Business and Entrepreneurship, Vol. 22, No. 1, pp.25-38.

Burns, P. (2001) Entrepreneurship and Small Business, Palgrave, Basingstoke.

Cannon, T. (1991) Enterprise: Creation, Development and Growth, Butterworth-Heinemann, Oxford.

Castells, M. and Portes, A. (1989) 'World underneath: the origins, dynamics and effects of the informal economy', in Portes, A., Castells, M. and Benton, L.A. (Eds.): The Informal Economy: Studies in Advanced And Less Developing Countries, John Hopkins University Press, Baltimore, pp.19-42.

Chernyshev, I. (2006) Socio-Economic Activity and Decent Work in Ukraine: A Comparative View and Statistical Findings, Working Paper, No. 76, ILO, Geneva.

Collins, O.F., Moore, D.G. and Unwalla, D.B. (1964) The Enterprising Man, East Lansing, Bureau of Business and Economic Research, Michigan State University, MI.

Cross, J.C. (1997) 'Entrepreneurship and exploitation: measuring independence and dependence in the informal economy', International Journal of Sociology and Social Policy, Vol. 17, Nos. 3-4, pp.37-63.

Cross, J.C. (2000) 'Street vendors, modernity and postmodernity: conflict and compromise in the global economy', International Journal of Sociology and Social Policy, Vol. 20, No. 1, pp.29-51.

Davis, M. (2006) Planet of Slums, Verso, London. 
De Soto, H. (1989) The Other Path: The Economic Answer to Terrorism, Harper and Row, London.

De Soto, H. (2001) The Mystery of Capital: Why Capitalism Triumphs in the West and Fails Everywhere Else, Black Swan, London.

Dees, J.G. (1998) The Meaning of Social Entrepreneurship, Duke University, Durham NC.

Dees, J.G. and Anderson, B.B. (2003) 'For-profit social ventures', International Journal of Entrepreneurship Education, Vol. 2, pp.1-26.

Defourny, J. and Nyssens, M. (2008) 'Social enterprise in Europe: recent trends and developments', Social Enterprise Journal, Vol. 4, No. 3, pp.202-228.

Deutschmann, C. (2001) 'Capitalism as religion? An unorthodox analysis of entrepreneurship', European Journal of Sociology, Vol. 44, pp.387-403.

Emerson, J. and Twersky, F. (1996) New Social Entrepreneurs: The Success, Challenge And Lessons Of Non-Profit Enterprise Creation, Roberts Foundation, Homeless Economic Development Fund, San Francisco.

European Commission (2007) Stepping Up The Fight Against Undeclared Work, European Commission, Brussels.

Evans, M., Syrett, S. and Williams, C.C. (2006) The Informal Economy and Deprived Neighbourhoods: A Systematic Review, Department of Local Government and Regions, London.

Fournier, V. (1998) 'Stories of development and exploitation: militant voices in an enterprise culture', Organization, Vol. 61, pp.107-128.

Friman, H.R. (2001) 'Informal economies, immigrant entrepreneurship and drug crime in Japan', Journal of Ethnic and Migration Studies, Vol. 27, No. 2, pp.313-133.

Frith, K. and McElwee, G. (2008) 'An emergent entrepreneur? A story of a drug dealer in a restricted entrepreneurial environment', Society and Business Review, Vol. 3, No. 2, pp.270-286.

Frith, K. and McElwee, G. (2009) 'Value-adding and value-extracting entrepreneurship at the margins', Journal of Small Business and Entrepreneurship, Vol. 22, No. 1, pp.39-54.

Galera, G. and Borzega, C. (2009) 'Social enterprise: an international overview of its conceptual evolution and legal implementation', Social Enterprise Journal, Vol. 5, No. 3, pp.210-228.

Gallin, D. (2001) 'Propositions on trade unions and informal employment in time of globalization', Antipode, Vol. 19, No. 4, pp.531-549.

Gerxhani, K. (2004) 'The informal sector in developed and less developed countries: a literature survey', Public Choice, Vol. 120, No. 2, pp.267-300.

Gurtoo, A. (2009) 'Policy support for informal sector entrepreneurship: micro-enterprises in India', Journal of Developmental Entrepreneurship, Vol. 14. No. 2, pp.181-194.

Gurtoo, A. and Williams, C.C. (2009) 'Entrepreneurship and the informal sector: some lessons from India', International Journal of Entrepreneurship and Innovation, Vol. 10, No. 1, pp.55-62.

Hanson, M. (2006) Transition In Ukraine, NATO Parliamentary Assembly, report number 065 Escew $06 \mathrm{E}$.

Harding, R., Brooksbank, D., Hart, M., Jones-Evans, D., Levie, J., O’Reilly, J. and Walker, J. (2005) Global Entrepreneurship Monitor United Kingdom 2005, London Business School, Global Entrepreneurship Monitor, London.

Hynes, B. (2009) 'Growing the social enterprise: issues and challenges', Social Enterprise Journal, Vol. 5, No. 2, pp.114-125.

International Labour Office (2002a) Decent Work and the Informal Economy, International Labour Office, Geneva.

International Labour Office (2002b) Women and Men in the Informal Economy: A statistical Picture, International Labour Office, Geneva. 
Jones, C. and Spicer, A. (2005) 'The sublime object of entrepreneurship', Organization, Vol. 12, pp.223-246.

Jones, C. and Spicer, A. (2006) 'Outline of a genealogy of the value of the entrepreneur', in: Erreygers, G. and Jacobs, G. (Eds.): Language, Communication and the Economy, John Benjamins Amsterdam, pp.124-142.

Kets de Vries, M.F.R. (1977) 'The entrepreneurial personality: a person at the crossroads', Journal of Management Studies, Vol. 2, No. 1, February, pp.34-57.

Kitchen, R. and Tate, N. (2001) Conducting Research in Human Geography: Theory, Practice and Methodology, Prentice Hall, London.

Knott, J. and Miller, G. (2006) 'Social welfare, corruption and credibility', Public Management Review, Vol. 8, No. 2, pp.227-252.

Leonard, M. (1994) Informal Economic Activity in Belfast, Avebury, Aldershot.

Llanes, M. and Barbour, A. (2007) Self-Employed and Micro-Entrepreneurs: Informal Trading and the Journey Towards Formalization, Community Links, London.

Lyon, F. and Sepulveda, L. (2009) 'Mapping social enterprises: past approaches, challenges and future directions', Social Enterprise Journal, Vol. 5, No. 1, pp.83-94.

MacDonald, R. (1994) 'Fiddly jobs, undeclared working and the something for nothing society', Work, Employment and Society, Vol. 8, No. 4, pp.507-530.

Mair, J. and Martí, I. (2005) 'Social entrepreneurship research: a source of explanation, prediction and delight', Journal of World Business, Vol. 41, No. 1, pp.36-44.

Maloney, W.F. (2004) 'Informality revisited', World Development, Vol. 32, No. 7, pp.1159-1178.

Mason, C., Carter, S. and Tagg, S. (2009) Invisible Businesses: The Characteristics of Home-Based Businesses in the United Kingdom, Working paper 08-01, University of Strathclyde Business School, Glasgow.

Moisala, J. (2004) Earnings in Europe: A Comparative Study On Wages and Income Disparities in The European Union, Labour Institute for Economic Research, Helsinki.

Moore, C.W., Petty, J.W., Palich, L.E. and Longnecker, J.G. (2010) Managing Small Business: An Entrepreneurial Emphasis, South-Western Cengage Learning, London.

Nicholls, A. and Cho, A. (2006) 'Social entrepreneurship: the structuration of a field', in Nicholls, A. (Ed.): Social Entrepreneurship: New Models of Sustainable Social Change, Oxford University Press, Oxford, pp.99-118.

Packard, T. (2007) Do Workers in Chile Choose Informal Employment? A Dynamic Analysis of Sector Choice, World Bank Latin American and the Caribbean Region Social Projection Unit, Washington DC.

Pahl, R.E. (1984) Divisions of Labour, Blackwell, Oxford.

Perry, G.E. and Maloney, W.F. (2007) 'Overview: Informality - exit and exclusion', in Perry, G.E., Maloney, W.F., Arias, O.S., Fajnzylber, P., Mason, A.D. and Saavedra-Chanduvi, J. (Eds.): Informality: Exit and Exclusion, World Bank, Washington DC, pp.142-183.

Portes, A. (1994) 'The informal economy and its paradoxes', in Smelser, N.J. and Swedberg, R. (Eds.): The Handbook of Economic Sociology, Princeton University Press, Princeton, pp.126-153.

Ram, M., Edwards, P. and Jones, T. (2007) 'Staying underground: informal work, small firms and employment regulation in the United Kingdom', Work and Occupations, Vol. 34, No. 3, pp.318-344.

Rehn, A. and Taalas, S. (2004) '“Znakomstva I Svyazi!' [Acquaintances and connections]: blat, the Soviet Union and mundane entrepreneurship', Entrepreneurship and Regional Development, Vol. 16, No. 3, pp.235-250.

Renooy, P., Ivarsson, S., van der Wusten-Gritsai, O. and Meijer, R. (2004) Undeclared Work in an Enlarged Union: Analysis of Shadow work - An In-depth Study of Specific Items, European Commission, Brussels. 
Reynolds, P., Bygrave, W.D., Autio, E. and Hay, M. (2002) Global Entrepreneurship Monitor: 2002 Executive Monitor, London Business School, London.

Rose, R. (2005) Insiders and Outsiders: New Europe Barometer 2004, Glasgow: Studies in Public Policy 404, Centre for the Study of Public Policy, University of Strathclyde.

Round, J., Williams, C.C. and Rodgers, P. (2008) 'Corruption in the post-Soviet workplace: the experiences of recent graduates in contemporary Ukraine', Work, Employment and Society, Vol. 22, No. 1, pp.149-166.

Sköld, D. and Rehn, A. (2007) 'Makin' it, by keeping it real: street talk, rap music and the forgotten entrepreneurship from the 'hood", Group and Organization Management, Vol. 32, No. 1, pp.50-78.

Small Business Council (2004) Small Business in the Informal Economy: Making the Transition to the Formal Economy, Small Business Council, London.

Smallbone, D. and Welter, F. (2004) Entrepreneurship in Transition Economies: Necessity or Opportunity Driven?, www.babson.edu/entrep/fer/BABSON2003/XXV/XXV-S8/xxv-s8.htm (last accessed 9 November 2010)

Smith, R. (2007) 'Special issue: Listening to the voices from the margins of entrepreneurship', International Journal of Entrepreneurship and Innovation, Vol. 8, No. 4, pp.245-250.

Smith, R. and Christou, M.L. (2009) 'Extracting value from their environment: some observations on pimping and prostitution as entrepreneurship', Journal of Small Business and Entrepreneurship, Vol. 22, No. 1, pp.69-84.

Snyder, K.A. (2004) 'Routes to the informal economy in New York's East village: crisis, economics and identity', Sociological Perspectives, Vol. 47, pp.215-240.

Storr, V. and Butkevich, B. (2007) 'Subalternity and entrepreneurship: tales of marginalized but enterprising characters, oppressive settings and haunting plots', International Journal of Entrepreneurship and Innovation, Vol. 8, No. 4, pp.251-260.

Thompson, J.L. (2008) 'Social enterprise and social entrepreneurship: Where have we reached? A summary of issues and discussion points', Social Enterprise Journal, Vol. 4, No. 2, pp.149-161.

Transparency International (2005) Report on the Transparency International Global Corruption Barometer 2005, http://transparency.org/policy_research/surveys_indices/gcb

Valenzuela, A. (2001) 'Day labourers as entrepreneurs', Journal of Ethnic and Migration Studies, Vol. 27, No. 2, pp.335-352.

Williams, C.C. (2004) Cash-in-Hand Work: The Underground Sector and the Hidden Economy of Favours, Palgrave Macmillan, Basingstoke.

Williams, C.C. (2006) The Hidden Enterprise Culture: Entrepreneurship in the Underground Economy, Edward Elgar, Cheltenham.

Williams, C.C. (2007a) 'Socio-spatial variations in the nature of entrepreneurship', Journal of Enterprising Communities, Vol. 1, No. 1, pp.27-37.

Williams, C.C. (2007b) 'De-linking enterprise culture from capitalism and its public policy implications', Public Policy and Administration, Vol. 22, No. 4, pp.461-474.

Williams, C.C. (2007c) 'Do entrepreneurs always play by the rulebook?', Management Online Review, April, pp.1-18, http://www.morexpertise.com/download.php?id=61

Williams, C.C. (2007d) 'The nature of entrepreneurship in the informal sector: evidence from England', Journal of Developmental Entrepreneurship, Vol. 12, No. 2, pp.239-254.

Williams, C.C. (2008) 'Beyond necessity-driven versus opportunity-driven entrepreneurship: a study of informal entrepreneurs in England, Russia and Ukraine', International Journal of Entrepreneurship and Innovation, Vol. 9, No. 3, pp.157-166.

Williams, C.C. (2009a) 'Beyond legitimate entrepreneurship: the prevalence of off-the-books entrepreneurs in Ukraine', Journal of Small Business and Entrepreneurship, Vol. 22, No. 1, pp.55-68. 
Re-thinking informal entrepreneurship: Commercial or social entrepreneurs? 309

Williams, C.C. (2009b) 'Entrepreneurship and the off-the-books economy: some lessons from England', International Journal of Management and Enterprise Development, Vol. 7, No. 4, pp.429-444.

Williams, C.C. and Round, J. (2007) 'Entrepreneurship and the informal economy: a study of Ukraine's hidden enterprise culture', Journal of Developmental Entrepreneurship, Vol. 12, No. 1, pp.119-136.

Williams, C.C. and Round, J. (2008) 'The hidden enterprise culture of Moscow: entrepreneurship and off-the-books working practices', Journal of Developmental Entrepreneurship, Vol. 13, No. 4, pp.445-462.

Williams, C.C., Round, J. and Rodgers, P. (2009) 'Evaluating the motives of informal entrepreneurs: some lessons from Ukraine', Journal of Developmental Entrepreneurship, Vol. 14, No. 1, pp.59-71.

Zadek, S. and Thake, S. (1997) 'Send in the social entrepreneurs', New Statesman, Vol. 26, p.31. 